\title{
Islamic Numismatics
}

\author{
Atef Mansour M Ramadan* \\ Dean of Faculty of Archaeology, Fayoum University, Egypt
}

*Corresponding author: Atef Mansour M Ramadan, Professor of Islamic Numismatics, Dean of Faculty of Archaeology, Fayoum University, Egypt

\section{Editorial}

Islamic Numismatics represent a significant field of study in Islamic history, archeology and civilization. In this regard, Miles states in the introduction of his book about the Numismatic History of Rayy: "No field of history is so well served by its numismatics as is the Islamic" [1].

Numismatics have received special attention in the Islamic State. In fact, Islamic legislation 'Shari'a' has been interested in coins in terms of worship and transactions, due to the connection between coins and zakat, dowry, contracts, waqf, diya and others. Numismatics also played a significant role in the Islamic State not only as an important tool for the economic system, but also as the governmental media system that resembles diverse modern mass media, such as radio, television, newspapers, magazines, and more. Such significant role attains to coins' rapid circulation and widespread, for all hands hold it and all eyes envision it.

Islamic coins played an integral role in political life during the Islamic State in an unprecedented way throughout the ages, because of their significance in the political system since the beginning of Islam. Numismatics represented the most important emblems of kings and sultans that the caliphs and rulers were keen on immediately obtaining after holding power. That is, the caliph or ruler had to announce ruling through major procedures, the first of which was to struck numismatics under his name, making supplications in the Friday sermon, and inscribing his name on tiraz [2].

Numismatics were the main means of communication between the caliph or the ruler and his people through which he transmitted the principles of his reign and the foundations upon which it was based. Numismatics were also used to announce important statements to the people and to record the major events the State witnessed. Therefore, the study of Islamic numismatics was particularly important to know the political systems of the various Muslim states as an official document issued by the State Mint -under the ruler's command-whose value is difficult to question or challenge.
Historians have depended -in their diverse disciplines-on coins in the study of the various aspects of history and Islamic civilization, benefitting from numismatics in the interpretation of many historical phenomena and in asserting and denying the authenticity of information in different historical sources.

Islamic numismatics are a huge record of names and titles belonging to different figures in Islamic states, such as Caliphs, rulers, sultans, kings, governors, workers, ministers, crown princes, militaries, police officers and kharaj (taxes) holders, mint supervisors and workers, renowned women, doctors, assistants, servants, slaves, market supervisors and others, which makes Islamic numismatics an important source in the study of the political and administrative systems of the Islamic State in various historical periods. The following are examples of the most important names struck on Islamic numismatics:

\section{Names of Caliphs, Rulers, Sultans and Kings}

The importance of Islamic numismatics lies in the fact that the names of Caliphs and rulers who struck it were recorded on them except for a few. Therefore, by classifying Islamic numismatics, it was possible to obtain lists of the dynasties, families, and ruling states in the Muslim world, and to even date their reign more precisely. This is because Islamic coins often carried their date of struck.

In fact, Islamic numismatics were characterized by relatively high authenticity in this respect, because, as abovementioned, numismatics represented the king and the sultan and were an important sign of reign and sovereignty, Therefore, the caliphs and rulers upheld this right and did not allow anyone to claim it. Whoever struck coins without the approval of the caliph or the ruler was considered a rebel against him and a dispute on his property. This was confirmed by Abu Ya'li when he said: “To struck numismatics without the approval of the Sultan was prevented for being considered a rebellion against him" [3]. 
Numismatics struck without the approval of the Sultan by rebels and protestors were not permissible for circulation and were often even not recognized, which is clearly evident in what al-Mawardi stated in identifying the types of coins approved in kharaj (taxes), as he said: "... what is struck is reliable (meaning under the name of the Sultan) and therefore was accepted in payments of the so-called sales prices and consumed values. If the struck numismatics are of different value but of equal quality, the taxes holder demanded the one of highest value. That is, if it was struck by the Sultan of the time, the worker would accept it, for refusing it would be a rebellion against the Sultan. However, if the numismatics were struck by someone else, the worker would have to consider if the numismatics were of equal value to what is taken in kharaj, he would accept it, if not of equal value, then claiming the numismatics would be unjust and unfair [4].

The rebels and protestors recognized the importance of numismatics as a means of addressing the people and spreading their ideas and the principles of their revolutions, in an attempt to attract the support of the people, which attained success to many of them in these revolutions. Not only that, but the rebels and protestors struck numismatics as a significant manifestation of governance, sovereignty and independence, standing against the ruler through the king's major emblem, which is to struck numismatics. Therefore, the rebels and protestors were keen on making numismatics struck under their names to express their power and their total independence from the ruler against whom they revolted.

The numismatics of the rebels gained special importance in the study of Islamic history and civilization because they are regarded as unquestionable proof of their owners' rebellion against the Sultan of the state. Moreover, the periods in which these numismatics were struck were often short, and revolutionary numismatics were few -as compared to state numismatics - because the rulers of the different states melted such coins and struck them in accordance with the general form of the state, which reflects the popularity of revolutionary coins and the legitimacy of their circulation. Certainly, these revolutionary coins were not allowed for circulation inside the state, since they were illegal numismatics bearing the name of a usurper of power and did not bear the name of the legitimate Sultan of the country, but this does not deny the relative spread of such revolutionary numismatics in the cities and territories controlled by these rebels. Since the rebels were keen on legitimatizing their numismatics for circulation, or on encouraging people to use such numismatics, prompted them to struck these coins properly in high quality and often with adequate weight. Yet, some rebels struck coins that did not conform to the weight and legal quality of contemporary revolutionary numismatics for they were intended for propaganda and media only.

Therefore, the collections of Islamic numismatics preserved in museums, palaces and private collections holders have received the attention of researchers in the field of Islamic numismatics since the 18th century A.D., for they collected, categorized and published them in special catalogs on Islamic numismatics. Since then, interest in the study of Islamic numismatics has not ceased, either in terms of publishing the collections of numismatics preserved in many museums and international private collections; a field of interest for many scholars, or in terms of conducting analytical studies to make use of such coins in the study of Islamic history and civilization for coins are regarded as one of the most important sources in Islamic history; a field of interest that began later than the former, for these analytical studies have started since the middle of the last century. Some researchers dealt with numismatics from the legitimacy point of view as an important tool for the payment of zakat, while others attempted to make use of such numismatics as one of the significant sources in Islamic history and civilization, conducting analytical studies to reveal the different aspects of life in the Islamic community as reflected on the coins of that era. In addition, other studies aimed at benefiting from this important source.

The study of Islamic numismatics and the passion for it was not limited to researchers and specialists in this field, but also extended to other collectors who loved this significant branch of archaeological studies and exerted distinct effort in being keen on purchasing and collecting various numismatics, through which such collectors found great pleasure, relieving their physical and moral issues for obtaining these numismatics.

\section{References}

1. Miles George C (1938) The Numismatic History of Rayy. New York, USA, p. 3.

2. These are the three main emblems of the king. Ibn Khaldun has pointed to many other emblems such as tools (brigades, banners, drums, and horns), the bed, the pulpit, the takht, the chair, the ring, the gardens, the fence, the prayer compartment, and others. For more details, see: Ibn Khaldun (Abdul Rahman bin Mohammed d. 808 AH): Ibn Khaldun Introduction. Dar Al-Jeel, Beirut ND pp. 284-298.

3. Abu Ya'li (1987) (Mohammed bin al-Hussein al-Faraa al-Hanbali d. 458 AH: The sultanate provisions. Reviewed by: Mohammed Hamid al-Feki. ( $3^{\text {rd }}$ edn), Halabi Foundation, Cairo, Egypt, pp. 188.

4. Al-Mawardi (1973) (Abu al-Hasan Ali bin Mohammed bin Habib al-Basri al-Baghdadi d. $450 \mathrm{AH}$ ): The sultanate and religious states provisions. ( $3^{\text {rd }}$ edn), Halabi Foundation, pp. 155. 
This work is licensed under Creative

Commons Attribution 4.0 License

To Submit Your Article Click Here:

Submit Article

DOI: $10.32474 / J A A S .2019 .01 .000106$

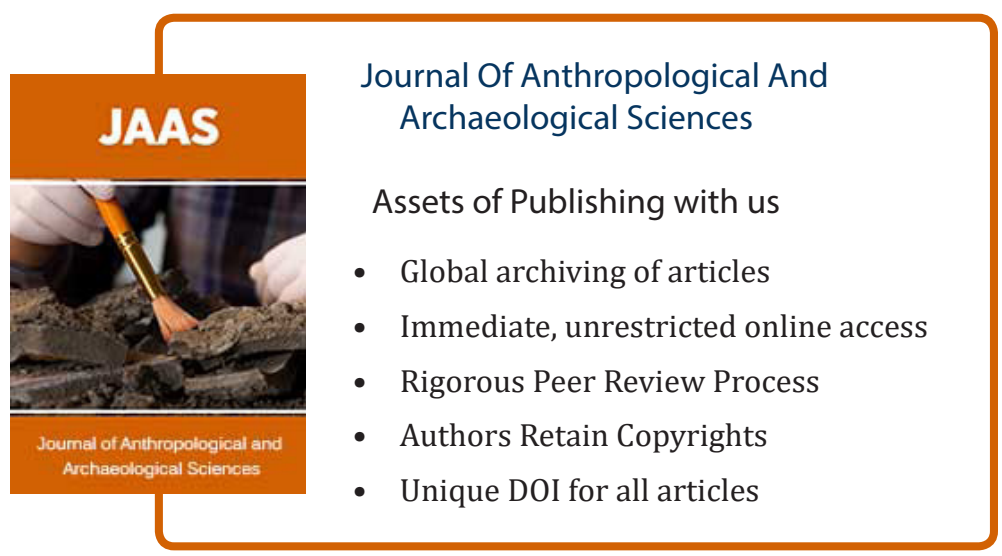

